\title{
Anencephaly: Case report and literature review
}

\section{Kamal El Moussaoui*, Sara El Bakkali, Ibrahim Ghrab, Aziz Baidada and Aicha Kharbach}

Department of Gynecology and Obstetrics, Maternity Souissi, University Hospital Center IBN SINA,

University Mohammed V, Rabat, Morocco
Received: 24 February, 2021

Accepted: 04 March, 2021

Published: 05 March, 2021

*Corresponding author: Dr. Kamal El Moussaoui, Department of Gynecology and Obstetrics, Maternity Souissi, University Hospital Center IBN SINA, University Mohammed V, Rabat, Morocco

E-mail: dr.elmoussaouikamal.gyn.obst@gmail.com

Keywords: Anencephaly; Diagnosis; Neural tube defects

https://www.peertechzpublications.com

Check for updates

\section{Abstract}

Anencephaly is a lethal fetal neurological malformation. This malformation accounts for $40 \%$ of neural tube malformations. The diagnosis is based on the ultrasound of the $1^{\text {st }}$ trimester between the $11^{\text {th }}$ and the $14^{\text {th }}$ weeks of amenorrhea by the discovery of an exencephaly which results in the visualization of the ossification of the cranial box and therefore of the impossibility to measure the biparietaldiameter. The objective of our work is to highlight the importance of an early ultrasonic diagnosis of anencephaly, which could help in a thorough evaluation and active management. Also, the main role of folic acid in the prevention in neural tube defects.

\section{Introduction}

Anencephaly is a congenital malformation of the central nervous system that results to the failure of closure of the cranial end of the embryologic neural tube, usually occurs between the $23^{\text {rd }}$ to $26^{\text {th }}$ days after conception.Anencephaly represents $40 \%$ of neural tube malformations, which is the second leading cause of nervous system abnormalities after spina bifida. The prevalence rate is $1 / 1,000$. The diagnosis is made by the $1^{\text {st }}$ trimester ultrasound between the $11^{\text {th }}$ and $14^{\text {th }}$ week. The causesare multifactorial (iatrogenic, toxic, metabolic, nutritionaland exceptionally chromosomal).

\section{Case report}

Mrs KD, 24 years old, rural geographical origin, the patient had no previous medical or surgical history, no notion of consanguinity, gravida 2, para 2. Her G1 was by vaginal delivery with episiotomy of a live born male of $3050 \mathrm{~g}, \mathrm{G} 2$ is the current pregnancy estimated at 36 weeksgiven by her last menstruation period. At 25 weeks of the pregnancy, she had gestational diabetes put on insulin therapyin the form of twice daily injections of insulin Glulisineand once daily injection of insulin Lispro was startedand dietary advice given, with notion of taking fenugreek and without taking any folic acid in preconception or in the $1^{\text {st }}$ trimester. Came to obstetric emergencies at the start of labor. There was no other significant past, obstetric, or surgical history. On general examination, the patient was clinically stable, height at $157 \mathrm{~cm}$, weight at $80 \mathrm{~kg}$, no edema of the lower limbs, blood pressure at $11 / 06 \mathrm{cmHg}, 88 \mathrm{bpm}, 98 \%$ saturation and temperature at 36.7 Obstetric examination: Active uterine contractions, $35 \mathrm{~cm}$ uterine height, the fetus was in longitudinal position, an active fetal heart beat, on vaginal examination a soft median cervix dilated to $2 \mathrm{~cm}$ cleared to $70 \%$ intact membrane in cephalic presentation. Emergency ultrasound reveals a single-fetal pregnancy, positive cardiac activity in cephalic presentation with anencephaly, a hydramnios with large cistern at $14 \mathrm{~cm}$ Figure 1.

The patient was transferred to the delivery room with monitoring. After 3 hours of labor, avaginal delivery without instrumental extraction of a newborn male birth weight $3250 \mathrm{~g}$,

Apgar score 6-7 at first and fifth minutes, respectively.A polymalformative syndrome: Clubbed feet, hands boots, hydrothorax and ventricular septal defect. The post-partum period without anomalies. Death of the newborn at $\mathrm{H} 7$ of life Figure 2.

\section{Discussion}

Anencephaly is a defect in the closure of the neural tube during fetal development. A baby born with anencephaly is usually blind and deaf. It is one of the most common types of neural tube defect, after spina bifida, affecting approximately 1 in 1,000 pregnancies. Diagnosis is made by $1^{\text {st }}$ trimester 


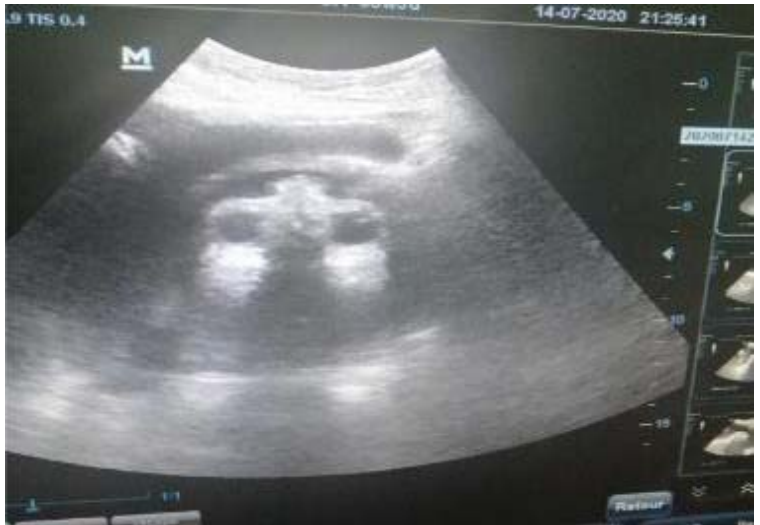

Figure 1: Ultrasound appearance showing anencephal.

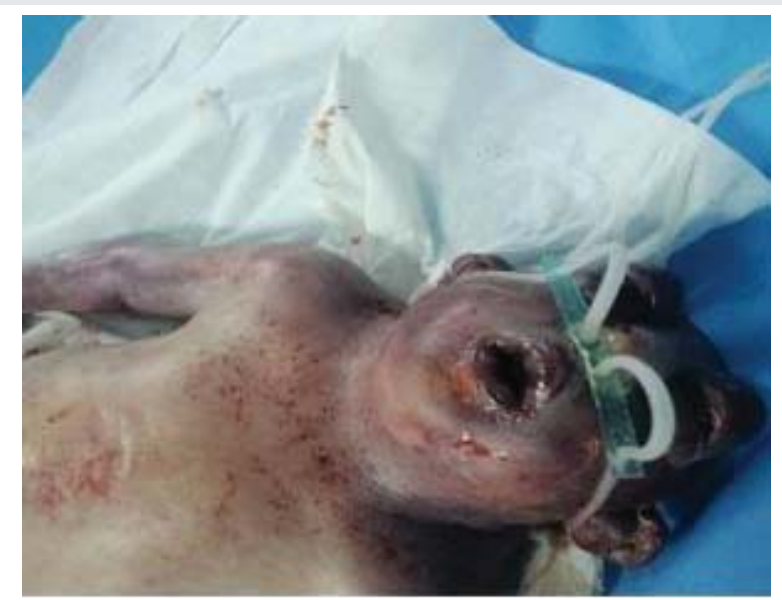

Figure 2: Newborn with anencephaly, low set ears and protruded eye ball.

ultrasound between $11^{\text {th }}$ and $14^{\text {th }}$ week of amenorrhea by the demonstration of exencephaly which results in the nonvisualization of the ossification of the cranial box and therefore the impossibility of measuring the biparietal diameter. Primary preventionof neural tube closure abnormalities by taking folic acid during the periconceptionalperiod has been shown to be effective. Neural Tube Defects (NTDs) (anencephaly, spina bifida, encephalocele) are the most common congenital malformations after heart and orofacial malformations [1]. Their causesremain obscure until now. In Morocco, the prevalence is around 10 cases per 10,000 births each year. Studies have shownthat woman who has had a first affected child has a higher risk than the rest of the population of having a second affected child $[1,2]$. In the study by Panduranga, et al. [3], all cases were detected between the 16 th and 34 th week of gestation with a mean gestational age of 21 weeks. As for Shilpa, et al. [4], he reports an average age of diagnosis of 22 weeks, varying between the $20^{\text {th }}$ and $30^{\text {th }}$ Week of Amenorrhea (WA). The study by Ekmekci, et al. [5] diagnosed anencephaly in 28 fetuses between 11 and 36 weeks old. The mean age of diagnosis was 18 weeks. As for N. Obeidi, et al. [6] the mean gestational age at diagnosis was $21+4$ WA with an interval between $13+4$ and 32+4 WA. Neural Tube Defects (NTDs) are more common in maternal insulin-dependent diabetes in the first trimester of pregnancy. The prevalence of these malformations varies from 4 to $15 \%$ ( $2.1 \%$ in the general population). The increased risk of malformation appears for modest hyperglycemia values. In absolute value, this risk elevated because it increase from $2 \%$ for an HbA1c of $5.5 \%$, to $6 \%$ for an HbA1c of $9 \%$ [7]. Fenugreek (Trigonellafoenum-graecum L.), in Arabic Helba, is one of the oldest medicinal and culinary plants, it is widely used in Morocco. It is an annual herb belonging to the Fabaceae family that is found all over the world, but it is of Mediterranean origin. In herbal medicine, the seeds of the plant are indicated in diabetics, for controlling glucose and cholesterol levels as well as for pregnant and lactating women $[8,9]$.

In the Maghrebregion, it is used in the treatment of wounds, diarrhea, acne, dehydration, anemia, bronchitis, rheumatism, stomachaches, constipationand arterialhypertension, either in the form of decoctions or of seeds reduced to flour and mixed with the honey [10]. The teratogenicityeffects of fenugreek in humans and animals have been demonstrated in several prospective studies. Also, cases of pronounced birth defects such as hydrocephalus, anencephaly, cleft palate and spina bifida have been found in women who consumed fenugreek seeds during pregnancy. Variously severalstudies have shown that fenugreek is neuroprotective [11,12], although, the developing nervous system appears to be particularly sensitive to the toxicity of fenugreek, as previously reported in Moroccan studies showing that children are more likely to develop encephalopathy such as hydrocephalus, anencephaly and spina bifida. Antenatal diagnosis of anencephaly in the first trimester is most successful for fetal abnormalities. In the second trimester ultrasound, the typical appearance of anencephaly is a sign of "frog eyes", due to the absence of visible brain tissue above the eye sockets. Hydramnios is defined as a pathological increase in the volume of amniotic fluid during pregnancy, the diagnosis is made by ultrasound. Hydramnios is associated with anencephaly in 30 to $50 \%$ of cases. The contributing factors include secretion of cerebrospinal fluidinto the amniotic cavity, lack of normal swallowing, lack of absorption of amniotic fluid by the hypoplastic lungs and excessive urine production due to lack of antidiuretic hormone. Hydramnios is the most common presentation of anencephaly before childbirth. Anencephaly is a uniformly lethal anomaly. It appears to be of multifactorial origin, so they are advised to consume foods rich in folic acid at least 3 months before planning their pregnancy and to maintain an appropriate intake if they are of childbearing age orpatients desirous of birth. Following studies carried out on primary and secondary prevention, Canadian, British and American organizations recommend that women of childbearing age consume $0.4 \mathrm{mg}$ to $0.8 \mathrm{mg} /$ day of folic acidto reduce cases of anencephaly. For women who already have an affected child, the recommended dose is between 0.8 and $4 \mathrm{mg}$.

\section{Conclusion}

Anencephaly is a lethal malformation characterized by an absence of closure of the anterior of the neural tube with aplasia of the cortical architecture and absence of formation of the cranial box. It is the second neural tube defect after spina bifida. Its antenatal diagnosis is mainly based on obstetric ultrasound. The prognosis for anencephaly is grim. It is a uniformly lethal defect. Termination of pregnancy is the 
most logical approach, but is not practiced in our context due to religious beliefs. Unfortunately, in the absence of curative treatment, prevention is therefore essential and creating awareness among the people about the preventable causes of nutritional deficiency. Therefore, Folic acid plays an important role in preconception or in the 1st trimester.

\section{References}

1. Weber M, Dib M (2003) Acide folique et prévention des anomalies de fermeture du tube neural chez la femme épileptique traitée. Rev Neurol (Paris) 159: 165170. Link: http://bit.ly/3sMKmK7

2. Kanya S, Charan M, Nond R, Chopiew T, Pichit S, et al. (2008) Risk factors associated with the occurrence of frontoethmoidalencephalomeningocele. Eur J Paediatr Neurol 12: 102-107. Link: http://bit.ly/38azBJJ

3. Panduranga C, Kangle R, Suranagi VV, Pilli GS, Patil PV (2012) Anencephaly: A pathological study of 41 cases. J Sci Soc 39: 81-84. Link: http://bit.ly/2OiTG9G

4. Shilpa K, Ranganath $P$, Sumathi S (2018) Anencephaly: incidence, risk factors and biochemical analysis of mother. Int $J$ Cur Res Rev 11: 20-26. Link: https://bit.ly/3865V0c

5. Ekmekci E, Gencdal S (2019) What's Happening When the Pregnancies Are Not Terminated in Case of Anencephalic Fetuses. J Clin Med Res 11: 332-336. Link: http://bit.ly/3e8qxJm
6. Obeidi N, Russell N, Higgins JR, O'Donoghue K (2010) The Natural History of Anencephaly. Prenat Diagn 30: 357-360. Link: http://bit.ly/3qfV8aj

7. Guerin A, Nisenbaum R, Ray JG (2007) Use of maternal GHb concentration to estimate the risk of congenitalanomalies in the offspring of women with prepregnancy diabetes. Diabetes Care 30: 1920-1925. Link: http://bit.ly/3sHI3cm

8. Kakani RK, Anwer MM, Fenugreek (2012) Handbook of herbs and spices (second edition), volume 1. In: Woodhead publishing series in food science technology and nutrition. Cambridge, UK 286-298.

9. Taloubi LM, Rhouda H, Belahcen A, Smires N, Thimou A, et al. (2013) An overview of plants causing teratogenicity: fenugreek (Trigonella foenum graecum). Intern J Pharm Sci Res 4: 516. Link: http://bit.ly/3rhDhAS

10. Rahmani M, Toumi-Benali F, Hamel L, Dif MM (2015) Aperçu ethnobotanique et phytopharmacologique sur Trigonella foenum-graecum L. Phytothérapie. Link: https://bit.ly/3beiRDc

11. Kumar RT, Doreswamy K, Shrilatha B, Muralidhara (2002) Oxidative stress associated DNA damage in testis of mice: induction of abnormal sperms and effects on fertility. Mutat Res 513: 103-111. Link: http://bit.ly/3eaZbSG

12. Morani AS, Bodhankar SL, Mohan V, Thakurdesai PA (2012) Ameliorative effects of standardized extract from Trigonellafoenum-graecum L. seeds on painful peripheral neuropathy in rats. Asian Pac J Trop Med 5: 385-390. Link: http://bit.ly/3e9aOtw

\section{Discover a bigger Impact and Visibility of your article publication with} Peertechz Publications

\section{Highlights}

* Signatory publisher of ORCID

* Signatory Publisher of DORA (San Francisco Declaration on Research Assessment)

* Articles archived in worlds' renowned service providers such as Portico, CNKI, AGRIS, TDNet, Base (Bielefeld University Library), CrossRef, Scilit, J-Gate etc.

* Journals indexed in ICMJE, SHERPA/ROMEO, Google Scholar etc.

- OAI-PMH (Open Archives Initiative Protocol for Metadata Harvesting)

* Dedicated Editorial Board for every journal

* Accurate and rapid peer-review process

* Increased citations of published articles through promotions

* Reduced timeline for article publication

Submit your articles and experience a new surge in publication services (https://www.peertechz.com/submission).

Peertechz journals wishes everlasting success in your every endeavours.

Copyright: @ 2021 Moussaoui KE, et al. This is an open-access article distributed under the terms of the Creative Commons Attribution License, which permits unrestricted use, distribution, and reproduction in any medium, provided the original author and source are credited. 